\title{
GENETIC VARIABILITY AND YIELD POTENTIAL OF THREE SEMIEXOTIC MAIZE (Zea mays L.) POPULATIONS
}

\author{
VARIABILIDADE GENÉTICA E POTENCIAL PRODUTIVO EM TRÊS \\ POPULAÇÕES SEMIEXÓTICAS DE MILHO (Zea mays L.)
}

\author{
Aurilene Santos OLIVEIRA ${ }^{1}$; Edésio Fialho dos REIS ${ }^{2}$; Jose Branco de MIRANDA FILHO ${ }^{3}$; \\ Udenys Cabral MENDES ${ }^{4}$; Luana de Oliveira RODRIGUES ${ }^{5}$ \\ 1. Doutoranda em Agronomia, Universidade Federal de Uberlândia - UFU, Uberlândia, MG, Brasil; 2. Professor Associado \\ III, Programa de Pós Graduação em Agronomia, Universidade Federal de Goiás - UFG, Jataí, GO, Brasil; 3. Professor \\ Titular, Programa de Pós Graduação em Genética e Melhoramento de Plantas, Universidade de São Paulo - \\ ESALQ/USP, Piracicaba, SP, Brasil; 4. Doutorando em Agronomia, Universidade Estadual Paulista - UNESP, \\ Jaboticabal, SP, Brasil; 5. Ma. Eng. Agrônoma, Syngenta, Uberlândia, MG, Brasil. aurilene.s.oliveira@ hotmail.com
}

\begin{abstract}
The rapid increase of the maize crop in the last decades in Brazil, mainly in the Central West region, has encouraged the second crop (usually maize after soybean) in the same year. For that reason the need for the exploitation of new sources of germplasm seems to be apparent to attend the challenge to create new cultivars (populations or hybrids) adapted to the extremely varying environments. Following this principle, the objective of the present work was directed to the study of genetic variability and yield potential of three semiexotic populations (CRE-01, CRE-02, CRE-03) under the condition of second crop in the Southwest region of the State of Goiás (Brazil). In addition, one cycle of recurrent selection with half-sib families was completed in each population. Half-sib families from each population (200, 180 and 180, respectively) were evaluated in completely randomized block experiments with three replications in Jataí (GO). Parameters estimates were obtained for ear yield (EY), grain yield (GY), plant height (PH), ear height (EH), ear length (EL) and ear diameter (ED). The population means for GY were $5.68 \mathrm{t} / \mathrm{ha}, 5.83 \mathrm{t} / \mathrm{ha}$ and $5.83 \mathrm{t} / \mathrm{ha}$, which were around $70 \%$ of the hybrid check. The coefficients of heritability (family mean basis) varied from 0.36 to $0.70 ; 0.47$ to 0.69 ; and 0.39 to 0.68 for the respective populations. Estimates of the additive genetic variance for grain yield ( $\mathrm{g} / \mathrm{plant}$ ) were 316.1, 266.4 and 258.4; and the expected gain from selection were $11.8 \%, 10.1 \%$ and $9.3 \%$, respectively.
\end{abstract}

PALAVRAS-CHAVE: Exotic germplasm. Genetic parameters. Recurrent selection. Zea mays.

\section{INTRODUCTION}

The acreage of the maize crop in Brazil has increased spectacularly in the last decades, thus creating incentives for a second crop (usually maize after soybean) in many important agricultural areas. Such expansion was followed by a better use of modern technologies thus allowing to reach higher levels of productivity. The acreage for second crop maize increased from 356 thousand hectares in 1990 to approximately 1.5 million ha in 1995 (TSUNESHIRO; OKAWA, 1996), reaching 9 million ha and producing 46.2 million tons in the last year (2012/2013); for comparison, the first (normal) crop covered 7 million ha producing 35.2 million tons. The evolution of the second crop was from $24 \%$ in $2001 / 2001$ to $56 \%$ in the last year. The highest production of the second crop maize is concentrated in the Central West region, represented by the states of Mato Grosso, Mato Grosso do Sul and Goiás, that together cover around $67 \%$ of the second crop production of corn (CONAB, 2013).

Even cognizant on the importance of the maize crop (normal and second crop) expansion, other subjects must be taken into account in order to maximize its production and productivity. One important point is the appropriate choice and use of the available germplasm that, by the way, must be in accordance with the objectives of the breeding program. In this sense, broadening the genetic base, by exploiting new sources of germplasm (varieties, populations, composites, synthetics, races, etc.), including exotics, may be a recommended strategy for the conditions of the vast array of environments like those occurring in Brazil. Exotic germplasm has largely contributed to increase the variability and the efficiency of breeding programs for the development of cultivars (MIRANDA FILHO, 1992; REGITANO NETO et al., 1997; SANTOS et al., 2000). The development of commercial hybrids initiated with local germplasm represented by old varieties such as Cateto and Dente Paulista. After that an extraordinary advance occurred with the introduction of exotic germplasm, mainly Tuxpeño and related races of Mexico and Central America that largely contributed for the development of high yielding semident hybrids (MIRANDA FILHO; VIÉGAS, 1987). The importance of the introduction of the race Tuxpeño for the maize breeding in Brazil was stressed by Paterniani (1990). Several other introductions have contributed to the maize breeding programs along the time. In fact, several authors 
have long been emphasized the importance of incorporation of exotic germplasm in maize breeding programs (NASS et al., 2001), but the introductions have been below the acceptable level of adaptation, thus making difficult to attain the desirable objectives. Nevertheless, some experiences have been accumulated and surely will contribute to overcome inherent obstacles (PATERNIANI, 1990; TATER et al., 2004; GOODMAN 2005) in Brazil, most of the introduced germplasm has been from tropical origin, which makes amenable the problem of adaptation.

After incorporation or introgression of the exotic germplasm, the next phase is to establish means to get knowledge on the genetic properties of the new population, particularly on the genetic variability of important quantitative traits that are in some extent influenced by the environmental effect. In this sense, the additive genetic variance, the coefficient of heritability and the expected gain from selection are among the most important parameters that will provide information on the genetic structure of the breeding population (VENCOVSKY, 1987; FALCONER, 1981; CRUZ, 2005; HALLAUER et al., 2010). There are several genetic designs that can be used to estimate the genetic variance and its components (HALLAUER et al., 2010). However, the use of half-sib families has been commonly used for that purpose in Brazil (VENCOVSKY et al., 1988). Several other reports have corroborated this fact (CARVALHO et al., 2007; ANDRADE; MIRANDA FILHO, 2008; SOUZA et al., 2009; LIMA NETO; SOUZA JÚNIOR, 2009; FALUBA et al. 2010; KIST et al., 2010; CANDIDO et al., 2011).

The objective of this work was to evaluate the genetic variability and yield potential of three semiexotic populations for their use in recurrent selection programs, toward the development of germplasm specially adapted to the environmental conditions of the Southwestern region of the State of Goías.

\section{MATERIAL AND METHODS}

A sample of 682 inbred $\left(\mathrm{S}_{4}\right)$ lines previously selected for resistance to corn stunt complex were introduced from CIMMYT (Centro Internacional de Mejoramiento de Maíz y Trigo, Colombia). A selected sample of 51 lines was crossed with three local testers: P-3041, represented by the $F_{2}$ generation of the commercial hybrid (Pioneer HyBred Seeds); CMS-14C, an open pollinated population derived from Pool-25 (CIMMYT, Mexico) and released by CNPMS/EMBRAPA; and
ESALQ-PB23, a broad base population obtained from the cross ESALQ-PB2 (dent type) and ESALQ-PB3 (flint type). After evaluation, a sample of testcrosses representing each tester was intercrossed to develop three populations: CRE-01 $\equiv$ 38 lines x P-3041; CRE-02 $\equiv 39$ lines x CMS-14C; CRE-02 $\equiv 32$ lines $x$ ESALQ-PB23. After the synthesis of the three semiexotic populations (CRE01, CRE-02, CRE-03) samples of half-sib families of sizes 50, 70 and 50, respectively, were evaluated in Jataí (GO) in 2008. A mild selection with intensities 13/50, 18/70, and 11/50 was applied and the recombined samples of the selected families represent the base populations in the present project. Isolated blocks from each population were used to generate half-sib families by random open pollination. The number of families were 200, 180 and 180 in the sequence of populations, which were divided into four experiments of 50, 45 and 45 families, respectively. The yield trials were in completely randomized blocks with three replications in one location (Farm Três Fronteiras, region of Jataí, GO). Plots were $4.0 \mathrm{~m}$ long spaced $0.90 \mathrm{~m}$ apart with 20 plants per plot after thinning. The following traits were analyzed: $\mathrm{PH}$ - plant height $(\mathrm{cm}), \mathrm{EH}$ - ear height $(\mathrm{cm}), \mathrm{EL}$ - ear length $(\mathrm{cm}), \mathrm{ED}$ - ear diameter $(\mathrm{cm}), \mathrm{DR}$ - general disease resistance (notes: 1 - resistant to 9 - susceptible), EY - total ear weight (g/plot) and GY - grain weight (g/plot); both EY and GY were corrected by the linear regression of yield on the number of ears per plot, according to methodology suggested by Miranda Filho, J.B. (apud VENCOVSKY; BARRIGA, 1992). One commercial hybrid (DAS 2B-710) was used as check, intercalated at ten plots in each block. The analyses of variance were performed according to the model $Y_{i j}=m+f_{i}+b_{j}$ $+e_{i j}$ where $Y_{i j}$ is the experimental unit referring to the $i^{\text {th }}$ family in the $j^{\text {th }}$ block, represented by plot total (EY and GY) or sample means of five plants $(\mathrm{PH}, \mathrm{EH}, \mathrm{EL}, \mathrm{ED})$. In the model, $\mathrm{m}$ is the general mean, $f_{i}$ is the random effect of the $i^{\text {th }}$ family, $b_{j}$ is the random effect of the $\mathrm{j}^{\text {th }}$ block, and $\mathrm{e}_{\mathrm{ij}}$ is the error term (random effect) for plots. For the purposes of this work, the following expectations are of interest: $\mathrm{E}\left(\mathrm{f}_{\mathrm{i}}\right)=\mathrm{E}\left(\mathrm{e}_{\mathrm{ij}}\right)=0, \mathrm{E}\left(\mathrm{f}_{\mathrm{i}}^{2}\right)=\sigma_{\mathrm{f}}^{2}$ (genetic variance among half-sib families), and $\mathrm{E}\left(\mathrm{e}_{\mathrm{ij}}^{2}\right)=\sigma^{2}$ (plot-toplot error variance). In the analysis of variance the mean squares for Families and Error have the following expected values: $E\left(M_{f}\right)=\sigma^{2}+3 \sigma_{f}^{2}$ and $\mathrm{E}\left(\mathrm{M}_{\mathrm{e}}\right)=\sigma^{2}$. Table 1 shows the procedures for estimating parameters in populations. 
Table 1. Formulas for the estimation of quantitative parameters in populations represented by random samples of half-sib families.

\begin{tabular}{ll}
\hline Parameters & Estimates \\
\hline General mean & $\mathrm{m}_{0}=\frac{1}{\mathrm{IJ}} \Sigma \mathrm{Y}_{\mathrm{ij}}$ \\
Phenotypic variance among half-sib family means & $\hat{\sigma}_{\mathrm{HS}}^{2}=\frac{1}{3} \mathrm{M}_{\mathrm{f}}$ \\
Genetic variance among HS families & $\hat{\sigma}_{\mathrm{f}}^{2}=\frac{1}{3}\left(\mathrm{M}_{\mathrm{f}}-\mathrm{M}_{\mathrm{e}}\right)$ \\
Additive genetic variance (only for HS) & $\hat{\sigma}_{\mathrm{A}}^{2}=4 \hat{\sigma}_{\mathrm{f}}^{2}$ \\
Error variance & $\hat{\sigma}^{2}=\mathrm{M}_{\mathrm{e}}$ \\
Coefficient of heritability (family mean basis) & $\mathrm{h}_{\mathrm{f}}^{2}=\left(\mathrm{M}_{\mathrm{f}}-\mathrm{M}_{\mathrm{e}}\right) / \mathrm{M}_{\mathrm{f}}$ \\
Coefficient of variation & $\mathrm{CV} \%=100 \sqrt{\mathrm{M}_{\mathrm{e}}} / \mathrm{m}$ \\
Genetic coefficient of variation & $\mathrm{CVg} \%=100 \hat{\sigma}_{\mathrm{f}} / \mathrm{m}$ \\
Index of variation & $\theta=\mathrm{CVg} / \mathrm{CV}$ \\
Expected gain from selection & $\mathrm{G}_{\mathrm{s}}=\mathrm{d}_{\mathrm{s}} . \mathrm{h}_{\mathrm{f}}^{2}$
\end{tabular}

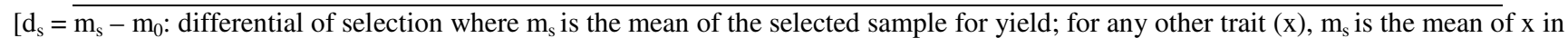
the same sample selected for yield].

\section{RESULTS AND DISCUSSION}

The analysis of variance for all traits in the three semiexotic populations showed significance $(F$ test; $\mathrm{P}<0.01)$ for the variation among families (Table 2). The coefficients of variations were in the range of $4.0 \%$ (ear diameter) to $11.1 \%$ (grain yield). The set of means for ear yield ( $t / h a)$ and grain yield $(t / h a)$ in the sequence [CRE-01, CRE-02, CRE-03] were [7.21, 7.39, 7.48] and [5.68, 5.83, 5.83], respectively. For check means, sets were [9.21, 9.22, 9.54] for EY and [8.01, 8.17, 8.28] for GY, so that in percent of check the family means were in the range of $78.3 \%$ to $80.2 \%$ for EY and around
$71 \%$ for GY; it is then clear that the ratio GY/EY for the hybrid check is much higher than for half-sib families in all three populations, averaging $87.5 \%$ and $78.5 \%$, respectively.

Ear yield and grain yield of the three semiexotic populations were considered in a good level, expressed as near $80 \%$ and around $70 \%$ of the hybrid check and this fact is attributable to the genetic base of the three testers used for introgression of the exotic germplasm. The results are similar to those found by Kist et al. (2010) in the open-pollinated population MPA, a wide base composite undergoing recurrent selection in the State of Santa Catarina.

Table 2. Mean squares ${ }^{\mathrm{K}}$ for Families $\left(\mathrm{M}_{\mathrm{F}}\right)$ and Error $\left(\mathrm{M}_{\mathrm{E}}\right)$, coefficients of variation $(\mathrm{CV} \%)$ and observed means (m) for six traits in three semiexotic populations.

\begin{tabular}{cccccccc}
\hline Population & $\mathrm{M}_{\mathrm{F}}$ & $\mathrm{M}_{\mathrm{E}}$ & $\mathrm{CV} \%$ & $\mathrm{~m}_{\mathrm{o}}$ & $\mathrm{m}_{\mathrm{H}}$ & $\mathrm{m}_{\mathrm{L}}$ & $\mathrm{m}_{\mathrm{C}}$ \\
\hline \multicolumn{7}{c}{ Plant height $(\mathrm{cm})^{\mathrm{a}}$} \\
\hline CRE-01 & $299.6^{* *}$ & 191.7 & 5.6 & 246.7 & 281.0 & 205.0 & 215.4 \\
CRE-02 & $277.6 * *$ & 148.6 & 4.9 & 247.7 & 284.0 & 211.0 & 222.2 \\
CRE-03 & $222.9 * *$ & 136.6 & 4.5 & 261.3 & 300.0 & 200.0 & 231.8 \\
\hline \multicolumn{7}{c}{ Ear height $(\mathrm{cm})^{\mathrm{a}}$} \\
\hline CRE-01 & $246.6 * *$ & 147.7 & 8.6 & 141.3 & 180.0 & 100.0 & 112.7
\end{tabular}


Genetic variability...

OLIVEIRA, A. S. et al.

\begin{tabular}{|c|c|c|c|c|c|c|c|}
\hline CRE-02 & $247.0 * *$ & 127.2 & 7.7 & 147.4 & 190.0 & 100.0 & 118.2 \\
\hline CRE-03 & $269.9 * *$ & 139.9 & 7.6 & 156.6 & 190.0 & 113.0 & 126.9 \\
\hline & \multicolumn{7}{|c|}{ Ear diameter $(\mathrm{cm})^{\mathrm{b}}$} \\
\hline CRE-01 & $0.086 * *$ & 0.041 & 4.3 & 4.7 & 5.3 & 4.0 & 4.9 \\
\hline CRE-02 & $0.128 * *$ & 0.044 & 4.5 & 4.7 & 5.5 & 4.0 & 4.8 \\
\hline \multirow[t]{2}{*}{ CRE-03 } & $0.087 * *$ & 0.037 & 4.0 & 4.7 & 5.5 & 4.3 & 4.9 \\
\hline & \multicolumn{7}{|c|}{ Ear length $(\mathrm{cm})^{\underline{b}}$} \\
\hline CRE-01 & $2.405 * *$ & 1.113 & 7.0 & 15.1 & 19.3 & 10.0 & 14.7 \\
\hline CRE-02 & $2.439 * *$ & 1.256 & 7.3 & 15.4 & 19.0 & 10.8 & 14.5 \\
\hline \multirow[t]{2}{*}{ CRE-03 } & $2.334 * *$ & 1.081 & 6.8 & 15.2 & 19.8 & 11.8 & 14.8 \\
\hline & \multicolumn{7}{|c|}{ Ear yield $(\mathrm{t} / \mathrm{ha})^{\underline{b}}$} \\
\hline CRE-01 & $546.5 * *$ & 164.1 & 9.9 & 7.21 & 9.78 & 4.83 & 9.21 \\
\hline CRE-02 & $516.3 * *$ & 162.9 & 9.6 & 7.39 & 10.1 & 4.56 & 9.22 \\
\hline \multirow[t]{2}{*}{ CRE-03 } & $429.4 * *$ & 137.1 & 8.7 & 7.48 & 10.1 & 4.83 & 9.54 \\
\hline & \multicolumn{7}{|c|}{ Grain yield $(\mathrm{t} / \mathrm{ha})^{\mathrm{b}}$} \\
\hline CRE-01 & $365.4 * *$ & 128.3 & 11.1 & 5.68 & 7.94 & 3.44 & 8.01 \\
\hline CRE-02 & $325.4 * *$ & 125.6 & 10.7 & 5.83 & 8.00 & 3.50 & 8.17 \\
\hline CRE-03 & $297.4 * *$ & 103.5 & 9.70 & 5.83 & 8.33 & 3.66 & 8.28 \\
\hline
\end{tabular}

${ }^{\mathrm{k}}$ Degrees of freedom for $\mathrm{M}_{\mathrm{F}}$ and $\mathrm{M}_{\mathrm{F}}$ : ${ }^{\mathrm{a}}$ [199 and 199 for CRE-01; 179 and 179 for CRE-02 and CRE-03]. ${ }^{\mathrm{b}}$ [199 and 398 for CRE-01;

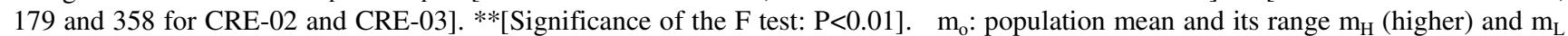
(lower); $\mathrm{m}_{\mathrm{C}}$ : hybrid check mean.

Figure 1 shows the grain yield ( $\mathrm{t} / \mathrm{ha}$ ) of halfsib families and their distribution (percentage) for the three semiexotic populations; a slight superiority on the average of CRE-03 is apparent in Figure 1. In fact, for EY and GY, expressed in percent of the hybrid check, the population means were [78.3,
$80.2,78.4]$ and $[70.9,71.4,70.4]$, respectively, in the sequence [CRE-01, CRE-02, CRE-03]. Even with means around $5.7 \mathrm{t} / \mathrm{ha}$, some families reached yields beyond $7.0 \mathrm{t} / \mathrm{ha}$ ( $\sim 85 \%$ of the hybrid check).

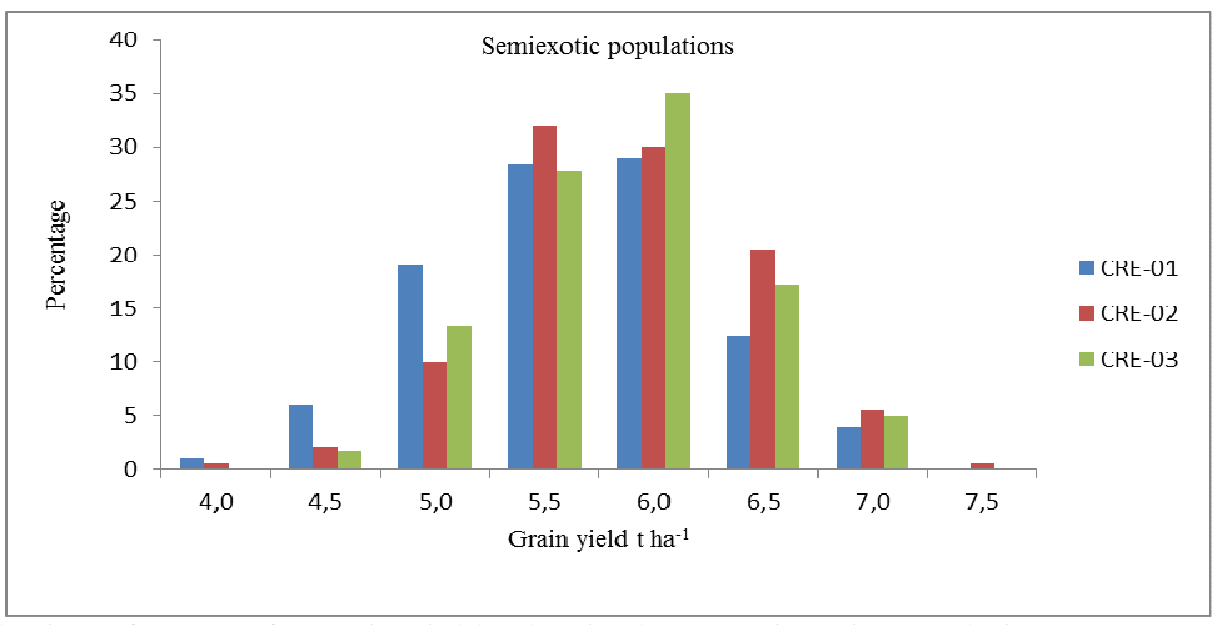

Figure 1. Distribution of means for grain yield (t/ha) in three semiexotic populations (CRE-01, CRE-02, CRE-

03). Jataí (GO), 2012.

For both $\mathrm{PH}$ and $\mathrm{EH}$ family means were in the order CRE-01<CRE-02<CRE-03, averaging $252 \mathrm{~cm}$ and $148 \mathrm{~cm}$, corresponding to $113 \%$ and $124 \%$ of the check, respectively. The observed means for $\mathrm{PH}$ and $\mathrm{EH}$ were classified as intermediate to high in the three populations, but the higher values were for CRE-03. In fact, the population used as base for the development of CRE-03 was a wide base composite from typically tropical gemplasm with the well known characteristic of tall plants and high ear placement. All the semiexotic populations also were taller than 
49 cultivars evaluated under second crop condition in five locations in the State of Goiás (CAMPOS et al., 2010), thus indicating the need of some strategy to decrease the plant height and ear placement toward a pattern of plant architecture that can be acceptable by the local corn growers.

Very small differences were observed for ED and EL among populations, which were around $4.7 \mathrm{~cm}$ and $15.3 \mathrm{~cm}$; on the average, ED was a little lower and EL a little higher than the hybrid check. Other authors have reported means in the range of $4.2 \mathrm{~cm}$ to $4.8 \mathrm{~cm}$ for ED and from $15.0 \mathrm{~cm}$ to $17.5 \mathrm{~cm}$ for EL (ANDRADE; MIRANDA FILHO, 2008; GARBUGLIO et al., 2009). On the other hand, the expression of ED and EL in the three populations did not differ greatly from six commercial hybrids grown in the region of Jataí (MARCHÃO et al., 2005).

In Table 3 are the estimates of parameters for six traits in the three populations. For EY and GY the phenotypic variance among half-sib family means (g/plant) averaged 166 and 110 while the genetic variance among families $\left(\sigma_{\mathrm{f}}^{2}\right)$ averaged 114 and 70 , respectively. The additive genetic variance $\left(\sigma_{\mathrm{A}}^{2}\right)$ is calculated directly from $\hat{\sigma}_{\mathrm{f}}^{2}$ and the sets of estimates in the order of populations were [509.9, 471.2, 389.7] and [316.1, 266.4, 258.4] for EY and GY, averaging 456.9 and 280.3, respectively; the averages were close to the upper limit of estimates (450 for EY and 333 for GY) reported by Santos and Miranda Filho (1992) for three semiexotic populations in two locations. For EY the estimate was within the range $250<\hat{\sigma}_{\mathrm{A}}^{2}<600$ shown by Miranda Filho e Nass (2001); the average of the three populations was similar to the estimate of 581.7 reported by Andrade e Miranda Filho (2008). Also, for GY the estimate was similar to the average $\left(306.1 \mathrm{~g}^{2}\right)$ of 45 estimates in Brazilian populations reported by Miranda Filho (1985) ; and close to 276.8 (average of three locations) given by Kist et al. (2010). For comparison, it is worthwhile to mention the estimates of $\sigma_{A}^{2}$ for GY reported by Hallauer \& Miranda Filho (1988), as 469.1 on the average of 99 estimates; the authors also mentioned 188.0 as the average of four experiments in the population BSSS (Iowa Stiff Stalk Synthetic) and 241.2 as the average in seven cycles of recurrent selection in the $\operatorname{BSK}(\mathrm{S})$ population. Other estimates at the interpopulation level were also given, as 386.3 (BSSS x BSCB1 as tester) and 373.8 (BSCB1 x BSSS as tester) in eight cycles of reciprocal recurrent selection.

The results of the three semiexotic populations under study, referring to variance estimates, indicate a good pattern of genetic variation for enabling them as base populations for a recurrent selection program in the Southwest region of the State of Goiás.

Estimates of the additive genetic variance $\left(\hat{\sigma}_{\mathrm{A}}^{2}\right)$ for PH and EH were within the range $170 \mathrm{~cm}^{2}<$ $\hat{\sigma}_{\mathrm{A}}^{2}<260 \mathrm{~cm}^{2}$, with low variation among populations, averaging $215.5 \mathrm{~cm}^{2}$ and $232.4 \mathrm{~cm}^{2}$; the estimates were a little lower for $\mathrm{PH}$ and a little higher for $\mathrm{EH}$, as compared to estimates (323.8 and 170.3) given by Andrade \& Miranda Filho (2008) and were also similar to the average (321.0 and 218.0 $\mathrm{cm}^{2}$, respectively) of 16 estimates summarized by Miranda Filho (1985) in Brazilian populations. The estimates were, however, greater for $\mathrm{PH}$ and about the same for EH in relation to 45 estimates summarized by Hallauer \& Miranda Filho (1988). Estimates higher than those herein observed were found by Candido et al. (2011) in the population Isanão (a brachytic composite) in which the higher variability may be the result of different expression of the brachytic gene $\left(b r_{2}\right)$ in the homozygous state in different genotypes. For PH the estimates also were very smaller than the average $\left(579.3 \mathrm{~cm}^{2}\right.$, over three locations) reported by Kist et al. (2010).

The sets of estimates of $\sigma_{\mathrm{A}}^{2}\left(\mathrm{x} 10^{2}\right)$ for ED and EL were $[6.00,11.20,6.67]$ and $[172.3,157.7$, 167.1], averaging 7.96 and 165.7, which are higher than the averages (3.9 and 142.3) of four experiments of BSSS population reported by Hallauer e Miranda Filho (1988); the same authors gave the average of 36 estimates as 4.6 and 152.4. The estimates given by Andrade e Miranda Filho (2008) for the population ESALQ-PB1 were 4.40 and 264.0, respectively. For EL, Santos e Miranda Filho (1992) reported values of 139.4, 96.2 and 191.6 in the local population E (ESALQ-PB1) and crosses E x EC (race Cravo) and E x EE (race Entrelaçado), respectively. Even with a restricted amount of information, the results clearly indicate that the populations under study have expressive variability for changing ear length and ear diameter by selection. 
Table 3. Estimates of the phenotypic variance among family means $\left(\hat{\sigma}_{\mathrm{HS}}^{2}\right)$, genetic variance among families $\left(\hat{\sigma}_{\mathrm{f}}^{2}\right)$, additive genetic variance $\left(\hat{\sigma}_{\mathrm{A}}^{2}\right)$, coefficient of heritability $\left(\mathrm{h}_{\mathrm{f}}^{2}\right.$ : family mean basis), genetic coefficient of variation $(\mathrm{CVg} \%)$, index of variation $(\theta)$, expected gain from selection (Gs) and expected gain from selection in percentage $(\mathrm{Gs} \%)$ for six traits in half-sib families of three semiexotic populations. Jataí (2012).

\begin{tabular}{|c|c|c|c|c|c|c|c|c|}
\hline \multirow[t]{3}{*}{ Population } & \multicolumn{8}{|c|}{ Parameters estimates } \\
\hline & $\hat{\sigma}_{\mathrm{HS}}^{2}$ & $\hat{\sigma}_{f}^{2}$ & $\hat{\sigma}_{A}^{2}$ & $\mathrm{~h}_{\mathrm{f}}^{2}$ & $\mathrm{CVg} \%$ & $\theta$ & $\mathrm{G}_{\mathrm{s}}$ & $\mathrm{G}_{\mathrm{s}} \%$ \\
\hline & \multicolumn{8}{|c|}{ Plant height $(\mathrm{cm})$} \\
\hline CRE-01 & 149.8 & 53.98 & 215.9 & 0.36 & 2.98 & 0.53 & -1.04 & -0.42 \\
\hline CRE-02 & 138.8 & 64.53 & 258.1 & 0.47 & 3.24 & 0.66 & 2.02 & 0.81 \\
\hline \multirow[t]{2}{*}{ CRE-03 } & 111.4 & 43.11 & 172.4 & 0.39 & 2.51 & 0.56 & 0.12 & 0.05 \\
\hline & \multicolumn{8}{|c|}{ Ear height $(\mathrm{cm})$} \\
\hline CRE-01 & 123.3 & 49.42 & 197.7 & 0.40 & 4.97 & 0.58 & -1.32 & -0.93 \\
\hline CRE-02 & 123.5 & 59.93 & 239.7 & 0.49 & 5.25 & 0.69 & 1.32 & 0.83 \\
\hline \multirow[t]{2}{*}{ CRE-03 } & 134.9 & 64.99 & 259.9 & 0.48 & 5.15 & 0.68 & -0.64 & -0.41 \\
\hline & \multicolumn{8}{|c|}{ Ear diameter $(\mathrm{cm})$} \\
\hline CRE-01 & 2.85 & 1.50 & 6.00 & 0.53 & 2.59 & 0.61 & 0.04 & 0.84 \\
\hline CRE-02 & 4.25 & 2.79 & 11.20 & 0.66 & 3.56 & 0.80 & 0.07 & 1.40 \\
\hline \multirow[t]{2}{*}{ CRE-03 } & 2.90 & 1.68 & 6.67 & 0.58 & 2.73 & 0.68 & 0.04 & 0.84 \\
\hline & \multicolumn{8}{|c|}{ Ear length $(\mathrm{cm})$} \\
\hline CRE-01 & 8.01 & 4.30 & 172.3 & 0.54 & 4.34 & 0.62 & 0.32 & 2.12 \\
\hline CRE-02 & 8.13 & 3.94 & 157.7 & 0.49 & 4.09 & 0.56 & 0.20 & 1.27 \\
\hline \multirow[t]{2}{*}{ CRE-03 } & 7.78 & 4.17 & 167.1 & 0.54 & 4.25 & 0.62 & 0.04 & 0.26 \\
\hline & \multicolumn{8}{|c|}{ Ear yield (g/plant) } \\
\hline CRE-01 & 182.2 & 127.5 & 509.9 & 0.70 & 8.70 & 0.88 & 14.98 & 11.54 \\
\hline CRE-02 & 172.1 & 117.8 & 471.2 & 0.69 & 8.16 & 0.85 & 14.12 & 10.62 \\
\hline \multirow[t]{2}{*}{ CRE-03 } & 143.1 & 97.43 & 389.7 & 0.68 & 7.33 & 0.84 & 11.95 & 8.870 \\
\hline & \multicolumn{8}{|c|}{ Grain yield (g/plant) } \\
\hline CRE-01 & 121.8 & 79.03 & 316.1 & 0.65 & 8.70 & 0.79 & 12.07 & 11.81 \\
\hline CRE-02 & 108.5 & 66.60 & 266.4 & 0.61 & 7.77 & 0.73 & 10.63 & 10.12 \\
\hline CRE-03 & 99.12 & 64.61 & 258.4 & 0.79 & 7.66 & 0.79 & 9.731 & 9.274 \\
\hline
\end{tabular}

The coefficient of heritability $\left(\mathrm{h}_{\mathrm{f}}^{2}\right)$ for family means indicates directly the level of expected response by selection of each trait under study. For the yield traits (EY and GY) the estimates were in the range of 0.60 to 0.80 , that can be considered in a good level for selection purposes; these estimates are much higher than the average of 0.34 and 0.35 given by Kist et al. (2010) and Miranda Filho e Nass (2001), for GY and EY, respectively. For plant and ear height, estimates of $\mathrm{h}_{\mathrm{f}}^{2}$ were much lower $(0.36$ to 0.49 ) than for the yield traits. Generally, the heritability is higher for $\mathrm{PH}$ and $\mathrm{EH}$ than for yield traits (EY and GY) because the later are more affected by the dominant gene action (HALLAUER; MIRANDA FILHO, 1988); in the present case, the results are explained by the genetic structure of the semiexotic populations, rather than on type of gene action controlling the trait. For the ear traits (ED and EL), the estimates of $h_{f}^{2}$ were considered relatively high (around 0.5), which are similar to the 0.56 and 0.66 reported by Andrade \& Miranda Filho (2008).

The index of variation $(\theta)$ is also related to the expected gain from selection and were above 0.5 for all traits in the three populations. Vencovsky e Barriga (1992) indicated that values of $\theta$ near or above 1.0 assure a favorable condition for selection. Here, the estimates were the lower $(0.53<\hat{\theta}<0.68)$ for $\mathrm{PH}$ and $\mathrm{EH}$, and medium $(0.56<\hat{\theta}<0.80)$ for ED and EL. For EY and GY, the sets of $\theta$ estimates were [ $0.88,0.85,0.84]$ and [ $0.79,0.73,0.79]$ averaging 0.857 and 0.770 , respectively, in the sequence of populations. In the present work, $\theta$ estimates did not follow the usual pattern of other studies. In fact, KIST et al. (2010) reported $\hat{\theta}<0.5$ 
( 0.418 on the average) for GY in three experiments of the population MPA; for $\mathrm{EH} \hat{\theta}$ values were around 1 (average 1.061). In the same way, Miranda Filho \& Nass (2001) reported results from five semiexotic populations, showing estimates in the range of $0.361<\hat{\theta}<0.661$ for $\mathrm{EY}, 0.702<\hat{\theta}<$ 0.934 for $\mathrm{PH}, 0.735<\hat{\theta}<0.987$ for $\mathrm{EH}, 0.190<\hat{\theta}$ $<0.664$ for $\mathrm{EL}$ and $0.416<\hat{\theta}<0.793$ for $\mathrm{ED}$; averaging $0.528,0.827,0.852,0.463$ and 0.598 , respectively.

After a final analysis of all the parameters related to genetic variability, it seems clear that yield traits were identified as the most promising for an effective selection. In fact, selection of the 20 higher yielding families was practiced in the three populations (CRE-01, CRE-02, CRE-03), representing selection intensities of $10.0 \%, 11.1 \%$ and $11.1 \%$, respectively. After recombination of the selected families in isolated blocks with openpollination, the expected effective size in the improved populations should be $\mathrm{Ne} \sim 80$ that is considered an appropriate number in recurrent selection programs. The expected gain from selection, as explained above, were $11.8 \%, 10.1 \%$ and $9.3 \%$, respectively, averaging $10.40 \%$. After one cycle of selection considering $10 \%$ yield gain, the expected means ( $\mathrm{t} / \mathrm{ha}$ ) would be $6.25,6.41$ and
6.41 , representing around $78 \%$ of the check yield. Under the same conditions (hypothesis of no changes in the genetic and environmental parameters), the expected mean of populations after two cycles of recurrent selection would be around $85 \%$ of the hybrid check.

The overall results of this work thus indicate that the three populations can be used successfully as base for a recurrent selection program toward the enhancement of their yield level, and agronomic traits at a less extent. The main purpose of this project seems to be achieved, that is to open the opportunity to make use of an interesting source of exotic germplasm, identified by the resistance to the corn stunt complex, by incorporation into local and adapted maize populations. In addition, because the tropical origin of the introduced germplasm, it can contribute immediately to widen the genetic variability of known or unknown characteristics of local breeding populations.

\section{ACKNOWLEDGMENTS}

The authors thank the National Council of Scientific and Technological Development (CNPq) for a scholarship granted to A. S. OLIVEIRA and the FAPESP for financial support.

RESUMO: O rápido aumento da cultura do milho nas últimas décadas no Brasil, principalmente na região Centro-oeste, causou incentivo para o milho "safrinha" (segunda cultura, geralmente milho após soja) no mesmo ano agrícola. Por esta razão, a necessidade de explorar novas fontes de germoplasma parece óbvia para atender ao desafio de criar novas cultivares (populações ou híbridos) adaptadas aos ambientes extremamente variáveis. Seguindo esta diretriz, o objetivo do presente trabalho foi direcionado ao estudo da variabilidade e do potencial produtivo de três populações semiexóticas (CRE-01, CRE-02, CRE-03) sob a condição de cultura de "safrinha" na região Sudoeste do Estado de Goiás (Brasil). Além disso, foi completado um ciclo de seleção recorrente com famílias de meios irmãos em cada população. As famílias de meios irmãos de cada população (200, 180 e 180, respectivamente) foram avaliadas experimentalmente em blocos casualizados com três repetições em Jataí (GO). Foram obtidas estimativas de parâmetros para produção de espigas $(\mathrm{EY})$ e de grãos (GY), altura da planta $(\mathrm{PH})$ e da espiga (EH) e comprimento (EL) e diâmetro (ED) da espiga. As médias populacionais para GY foram, respectivamente, 5,68 t/ha, 5,83 t/ha e $5.83 \mathrm{t} / \mathrm{ha}$, equivalendo a cerca de $70 \%$ do híbrido testemunha. Os coeficientes de herdabilidade (médias de famílias) variaram de 0,36 a 0,70;0,47 a 0,69; 0.39 a 0,68 para as respectivas populações. As estimativas da variância aditiva para produção de grãos (g/planta) foram 316,1; 266,4 e 258,4; e os ganhos esperados por seleção foram de 11,8\%,10,1\% e 9.3\%, respectivamente, para as três populações.

PALAVRAS-CHAVE: Germoplasma exótico. Parâmetros genéticos. Seleção recorrente,. Zea mays.

\section{REFERENCES}

ANDRADE, J. A. C.; MIRANDA FILHO, J. B. Quantitative variation in the tropical maize population, ESALQ-PB1. Scientia Agrícola, Piracicaba, v. 65, n. 2, p. 174-182, mar./abr. 2008. http://dx.doi.org/10.1590/S0103-90162008000200011 
CAMPOS, M. C. C.; SILVA, V. A.; CAVALCANTE, I. H. L.; MÁRKILA, Z. B. Produtividade e características agronômicas de cultivares de milho safrinha sob plantio direto no Estado e Goiás. Revista Acadêmica Ciência Agrária Ambiental, Curitiba, v. 8, n. 1, p. 77-84, jan./mar. 2010.

CANDIDO, L. S. et al. Seleção de progênies de meios-irmãos do composto Isanão VF-1 de milho na safra e safrinha. Ciência Rural, Santa Maria, v. 41, n. 6, p. 947-953, jun. 2011. http://dx.doi.org/10.1590/S010384782011005000072

CARVALHO, H. W. L.; SOUZA, E. M. Ciclos de seleção de progênies de meios-irmãos do milho BR 5011 Sertanejo. Pesquisa Agropecuária Brasileira, v. 42, p. 803-809, jun. 2007. http://dx.doi.org/10.1590/S0100204X2007000600006

COMPANHIA NACIONAL DE ABASTECIMENTO. Acompanhamento de safra brasileira: grãos, décimo levantamento, setembro 2013. Brasília, 2013. Disponível em: <http://www.conab.gov.br>. Acesso em: 15 out. 2013.

CRUZ, C. D. Princípios de Genética Quantitativa. 1ª Ed., Viçosa: Ed. UFV, v. 1, 2005. 394p.

FALCONER, D. S. Introdution to quantitative genetics. $2^{\text {nd }}$ ed. Longman, London. 1981. 340p.

FALUBA, J. S.; Lima, R. O.; Souza, L. V.; Debem, E. A. Oliveira, A.M.C. Potencial genético da população de milho UFV para o melhoramento em Minas Gerais. Ciência Rural, Santa Maria, v. 40, n. 6, p. 1250-1256, jun. 2010. http://dx.doi.org/10.1590/S0103-84782010000600002

GARBUGLIO, D. D.; MIRANDA FILHO, J. B.; CELLA, M. Variabilidade genetica em famílias $\mathrm{S}_{1}$ de diferentes populações de milho. Acta Scientiarum Agronomy, Maringá, v. 31, n. 2, p. 209-213, 2009. http://dx.doi.org/10.4025/actasciagron.v31i2.790

GOODMAN, M. M. Broadening the U.S. maize germoplasma base. Maydica, v. 50, p. 203-214. 2005.

HALLAUER, A. R.; MIRANDA FILHO, J. B. Quantitative genetics in maize breeding. ( $2^{\text {nd }}$ ed.). Iowa State University Press, Ames, IA. 1988.

HALLAUER, A. R.; CARENA, M. J.; Miranda Filho, J. B. Quantitative genetics in maize breeding. $3^{\text {rd }}$ edition, New York: Springer, 663p. 2010

KIST, V.; OGLIARI, J. B.; MIRANDA FILHO, J. B.; ALVES, A. C. Genetic potential of a maize population from Southther Brazil for the modified convergent-divergent selection scheme. Euphytica, v. 176, p. 25-36. 2010. http://dx.doi.org/10.1007/s10681-010-0207-y

LIMA NETO, F. P.; SOUZA JÚNIOR, C. L. Number of recomninations and genetic properties of a maize population undergoing recurrent selection. Scientia Agrícola, Piracicaba, v. 66, n. 1, p. 52-58, jan./fev. 2009.

MARCHÃO, R. L.; BRASIL, E. M.; DUARTE, J. B.; GUIMARÃES, C. M.; GOMES, J. A. Densidade de plantas e características agronômicas de híbridos de milho sob espaçamento reduzido entre linhas. Pesquisa Agropecuária Tropical, v. 35, n. 2, p. 93-101. 2005.

MIRANDA FILHO, J. B. Breeding Methodologies for Tropical Maize. In: Brandolini A and \& Salamini F (eds.), Breeding Strategies for Maize Production Improvement in the Tropics. Ist. Agron. per l'Oltremare (Firenze, Italy), 1985, p. 177-206.

MIRANDA FILHO, J. B. Exotic germoplasms introduced in a Brazilian maize breeding program. Brazilian Journal of Genetics, v. 15, p. 631-642. 1992. 
MIRANDA FILHO, J. B.; NASS, L. L. Genetic variability in semi-exotic populations of maize (Zea mays L.). Journal of Genetics and Breeding, v. 55, p. 191-200. 2001.

MIRANDA FILHO, J. B.; VIÉGAS, G. P. Milho Híbrido. In: PATERNIANI, E.; VIÉGAS, G. P. Melhoramento e produção do milho. Campinas: Fundação Cargill, 1987. v. 1, p. 277-340.

NASS, L. L; MIRANDA FILHO, J. B; SANTOS, M. X. Uso de germoplasma exótico no melhoramento. In: NASS, L. L.; VALOIS, A. C. C.; MELO I. S.; VALADARES-INGLIS, M. C. Recursos Genéticos e Melhoramento: Plantas, Rondonópolis: Fundação MT, 2001. p. 101-122.

PATERNIANI E. Maize breeding in the tropics. CRC Critical Review in Plant Science, v. 9, p. 125-154.1990.

REGINATO NETO, A.; NASS, L. L.; MIRANDA FILHO, J. B. Potential of twenty exotic germoplasms to improve Brazilian maize architecture. Brazilian Journal of Genetics, v. 20 p. 691-696. 1997.

SANTOS, M. X.; MIRANDA FILHO, J. B. Genetic potential of two Brazilian races of maize for breeding purposes. Journal Genetics \& Breeding, v. 46, p. 83-90. 1992.

SANTOS, M. X.; POLLAK, L. M.; PACHECO, C. A. P.; GUIMARÃES, P. E. O.; PETERNELLI, L. A.; PARENTONI, S. N.; NASS, L. L. Incorporating different proportions of exotic maize germoplasma into two adapted populations. Genetics and Molecular Biology, v. 23, p. 445-451. 2000.

http://dx.doi.org/10.1590/S1415-47572000000200033

SOUZA, A. R. R.; MIRANDA, G. V.; PEREIRA, M. G.; SOUZA, L. V. de. Predicting genetic gain in the Brazilian white maize landrace. Ciência Rural, v. 39, p. 19-24, 2009a. http://dx.doi.org/10.1590/S010384782009000100004

TATER, J. A.; GOODMAN, M. M.; HOLLAND, J. B. Recovery of exotic alleles in semiexotic maize inbreds derived from crosses between Latin American accessions and a temperate line. Theor Appl Genetic, v. 109, p. 609-617. 2004.

TSUNECHIRO, A.; OKAWA, H. Perspectivas da safrinha de milho em 1996. Informações Econômicas, v. 26, p. 87-89. 1996.

VENCOVSKY, R. Herança quantitativa. In: PATERNIANI, E. \& VIÉGAS, G. P. Melhoramento e produção de milho. 2.ed. Campinas: Fundação Cargil, 1987. p. 137-214.

VENCOVSKI, R.; BARRIGA, P. Genética biométrica no fitomelhoramento. Ribeirão Preto: Sociedade Brasileira de genética, 1992, 486p.

VENCOVSKY, R.; MIRANDA FILHO, J. B.; SOUZA JÚNIOR, C. L. Quantitative Genetics and Corn Breeding in Brazil. In: Weir B, Eisen B, Goodman MM and Namkoong N (eds.), Proc. of the Second International Conference on Quantitative Genetics. Sinauer Assoc. Inc., Sunderland (MA). Chap. v. 42, p. 465-477. 1988. 